\title{
Proteolytic Degradation of
}

\section{Exocrine and Serum Immunoglobulins}

\author{
William R. Brown, Richard W. Newcomb, and Kimishige Ishizaka \\ From the Department of Medicine, University of Colorado Medical Center, and \\ Children's Asthma Research Institute, Denver, Colorado 80204
}

A B S T R A C T The susceptibility of exocrine and serum immunoglobulins and antibodies to proteolytic degradation was assessed. Colostral and duodenal fluid exocrine $11 \mathrm{~S} \operatorname{IgA}$, monomeric serum $\operatorname{IgA}$, and $\operatorname{IgG}$ were digested with trypsin, chymotrypsin, or duodenal fluid. Exocrine IgA was more resistant to digestion than were the serum immunoglobulins. Under conditions of the experiments, most of colostral IgA retained its $11 \mathrm{~S}$ quaternary structure, including the secretory piece; the portion degraded was reduced almost entirely to peptides.

The superior resistance of exocrine IgA was also demonstrated by digestion of serum IgG and nasal exocrine IgA diphtheria antitoxins with trypsin or duodenal fluid. Selective precipitation of trypsin-digested antitoxins with antibodies to heavy chains, light chains, or secretory piece revealed that the differences in susceptibility to digestion were due to differences in lability of the $\mathrm{Fc}$ portions of the $\operatorname{IgA}$ and IgG antibody molecules. The Fc portions of IgG antibody molecules were degraded or cleaved from the Fab units of the molecules, whereas the Fc-like portions of $\operatorname{IgA}$ antibody molecules remained associated with their Fab-like units and the secretory piece. On the other hand, trypsin treatment did not affect the antigen binding ability of the Fab parts of either the exocrine IgA or IgG antibodies.

The Fc-like portions of exocrine IgA may be protected from tryptic degradation by the quaternary structure of the 11S molecules, which includes a dimer of $7 \mathrm{~S}$ $\operatorname{IgA}$ subunits and the secretory piece.

A preliminary report was made to the Midwest Section of the American Federation for Clinical Research and the Central Society for Clinical Research, Chicago, Ill., 1 November 1968; an abstract has been published (1).

Dr. Brown is supported in part by U. S. Public Health Service Special Fellowship 5 FO3 AM38896-02.

Received for publication 15 January 1970 and in revised form 5 March 1970.

\section{INTRODUCTION}

Exocrine $11 \mathrm{~S} \operatorname{IgA}$ is the predominant immunoglobulin of most human external secretions, including intestinal fluid (2-4), colostrum, and milk $(4,5)$. Antiviral and antibacterial antibodies of the IgA class (6-9) have been identified in these fluids, suggesting that exocrine $\operatorname{IgA}$ plays a role in the immune defenses of the gut. Because immunoglobulins in gastrointestinal fluids are exposed to potent proteolytic enzymes, their susceptibility to proteolytic degradation may influence their biological activities.

Evidence concerning the stability of antibodies and immunoglobulins exposed to proteolytic enzymes is meager and inconclusive. The biological activity of certain milk antibodies resisted pepsin digestion more effectively than did the activity of corresponding serum antibodies (9). The activities of other serum and exocrine antibodies were equally susceptible to tryptic (9, $10)$ or peptic (10) digestion. Tomasi and coworkers $(11,12)$ have stated that exocrine IgA resists digestion by several proteolytic enzymes which readily degrade serum immunoglobulins, but experimental evidence has not been published.

In this study, human exocrine and serum immunoglobulins and antibodies were digested with trypsin, chymotrypsin, or duodenal fluid. Susceptibility to digestion was assessed principally by the following two approaches: (a) digests of the immunoglobulins were fractionated by gel filtration, and the per cent of each immunoglobulin remaining intact was estimated from the spectrophotometric absorption curves or by radial immunodiffusion; and (b) diphtheria antitoxins prepared from nasal secretions or serum were digested, and the amounts of radio-labeled diphtheria toxoid bound by intact antibodies or by their fragments were estimated. The results indicated that exocrine $\operatorname{IgA}$ was more resistant to digestion than were $\operatorname{IgG}$ or serum $\operatorname{IgA}$, and 
that $\operatorname{IgA}$ antitoxin was more resistant than serum $\operatorname{IgG}$ antitoxin.

\section{METHODS}

Purification of immunoglobulins and diphtheria antitoxins. Colostral 11S IgA, the secretory piece (SP) free in colostrum, and serum IgG were purified as described (13). Colostral IgA and SP were purified by diethyl aminoethyl (DEAE)-cellulose (Mannex-DEAE, Mann Research Labs Inc., New York) and Sephadex (Pharmacia Fine Chemicals, New Market, N. J.) gel filtration from pooled, defatted colostrum which had been stored at $-20^{\circ} \mathrm{C}$. Monomeric serum $\operatorname{IgA}$ was prepared by a modification of the zinc sulfate method (14). The supernatant of the zinc sulfate precipitate, after addition of ethylenediaminetetraacetate (EDTA) and subsequent dialysis, was treated with $50 \%$ saturated ammonium sulfate at $\mathrm{pH}$ 7.8. The precipitate was twice filtered through a column of Sephadex G-200 $(2.5 \times 100 \mathrm{~cm})$. Protein was eluted by upward-flowing borate-buffered saline $(0.15 \mathrm{M} \mathrm{NaCl}$ in $0.01 \mathrm{M}$ borate buffer, $\mathrm{pH} 8.0$, containing $0.001 \mathrm{M}$ EDTA). The final preparation contained less than $5 \% \operatorname{IgG}$ and polymerized $\operatorname{IgA}$.

Monomeric $\operatorname{IgA}$ was prepared from 11S colostral $\operatorname{IgA}$ by reduction with $50 \mathrm{~mm}$ dithioerythritol and alkylation with iodoacetamide as described (13). The 7S peak was isolated by Sephadex G-150 gel filtration.

Diphtheria antitoxins were prepared from serum or secretions of adults who had been immunized either by nasal instillation or subcutaneous injection of diphtheria toxoid (15). Exocrine $\operatorname{IgA}$ antitoxin was purified from nasal secretions by DEAE-cellulose column chromatography and Sephadex G-200 gel filtration. IgG antitoxin was isolated from serum by DEAE-cellulose column chromatography.

Enzymes and duodenal fluid. Twice-crystallized Type 111 bovine pancreatic trypsin $(12,000 \mathrm{BAEE} \mathrm{U} / \mathrm{mg})$ was purchased from the Sigma Chemical Company, St. Louis, Mo. Bovine pancreatic alpha chymotrypsin (crystallized, saltfree, A grade, 1240 chymotrypsin neutral fraction [NF] U/ $\mathrm{mg}$ ) and soybean trypsin inhibitor (three-times crystallized, $B$ grade) were purchased from Calbiochem, Los Angeles, Calif. Stock solutions of the enzymes $(10 \mathrm{mg} / \mathrm{ml}$ in $0.001 \mathrm{~N}$ $\mathrm{HCl}$ ) were stored at $-20^{\circ} \mathrm{C}$. Duodenal fluid was aspirated from fasting adults, snap frozen, and stored for a few days to a few weeks at $-20^{\circ} \mathrm{C}$ before use. The subjects had various gastrointestinal disorders, but did not have pancreatic insufficiency; some were hypogammaglobulinemic.

Proteolytic activity of trypsin and duodenal fluid was estimated by casein digestion according to Kunitz (16). High protein casein was purchased from Calbiochem. Specific activity of the trypsin was $3.9 \times 10^{-3}$ Kunitz units. Tryptic hydrolysis of $p$-toluenesulphonyl-L-arginine methyl ester (TAME) was estimated by the method of Hummel (17) in Determatubes TAME (Worthington Biochemical Corp., Freehold, N. J.).

Gel filtration separation of digested immunoglobulins. Immunoglobulin digests were separated on a $1.5 \times 90 \mathrm{~cm}$ column of Sephadex G-150 in borate-buffered saline (downward flow at $4 \mathrm{ml} / \mathrm{hr}, 2^{\circ} \mathrm{C}$ ), and collected in $3-\mathrm{ml}$ fractions. The column had been calibrated with colostral $\operatorname{IgA}$, serum IgG, and human serum albumin.

Antisera to human immunoglobulins. Rabbit antibodies to human $\operatorname{IgG}, \operatorname{IgA}$, and $\mathrm{SP}$ were prepared as described $(13,15)$. Anticolostral IgA was made specific for SP by absorption with serum IgA; anti-serum IgA was made specific for $\alpha$ chains by absorption with IgG. The ab- sorbed antibody preparation did not react in double gel diffusion with the Fab fragments isolated from reduced-alkylated and trypsin digested exocrine IgA. Rabbit antibodies to the Fab fragment of normal human IgG were purified from specific precipitates by described methods (18).

Immunologic methods. Antigenic analysis of digested immunoglobulins was conducted by double diffusion in agar gel according to Ouchterlony (19). The concentrations of immunoglobulins in duodenal fluid were estimated by single radial immunodiffusion (20). Preparations of rabbit antibodies specific for the heavy chains of human IgA or IgG were included in the agar. Reference antigens were colostral $11 \mathrm{~S} \operatorname{IgA}$ and serum $\operatorname{IgA}$ and IgG. The concentration of $\operatorname{IgA}$ in gel filtration fractions was estimated in a single radial immunodiffusion system as described by Rowe (21), in which sensitivity of the system was increased by adding a step using radio-iodinated goat antibodies to rabbit $\boldsymbol{\gamma}$-globulin.

Digestion of diphtheria antitoxin and estimation of toxoid binding. Nasal fluid or serum antitoxin specimens were incubated with trypsin or duodenal fluid at a concentration of immunoglobulin $(20 \mu \mathrm{g}$ of $\mathrm{N}$ per $\mathrm{ml}$ or $0.13 \mathrm{mg}$ of protein per $\mathrm{ml})$ similar to that of $\operatorname{IgA}$ in normal duodenal fluid $(2-4)$ Digestion was conducted with trypsin: substrate ratios of $1: 23$ or $1: 10(\mathrm{w} / \mathrm{w})$ for 3 or $17 \mathrm{hr}$ at $38^{\circ} \mathrm{C}$ in $0.05 \mathrm{M}$ Tris$\mathrm{HCl}$ buffer, $\mathrm{pH}$ 8.0. Trypsin digestion was stopped by a 4-fold excess of soybean trypsin inhibitor. The amount of ${ }^{125} \mathrm{I}$-labeled diphtheria toxoid bound by IgA or IgG antitoxin was then estimated as described (22). Soluble antigen-antibody complexes were formed by incubation $(1 \mathrm{hr})$ of $0.2 \mathrm{ml}$ of digested antitoxin preparation with excess radio-labeled toxoid. (Duodenal fluid digests were incubated at $4^{\circ} \mathrm{C}$, trypsin digests at $38^{\circ} \mathrm{C}$.) Excess rabbit antibody specific for immunoglobulin heavy chains, light chains, or SP then was added to the appropriate antitoxin mixture in order to coprecipitate toxoid bound only to intact antibodies or to Fab fragments as well as to intact antibodies. Anti- $\gamma$ or anti-Fab antibodies were added to the IgG antitoxin mixtures; anti- $\alpha$, anti-SP, or anti-Fab antibodies were added to the IgA antitoxin mixtures. Control (undigested) antitoxins were handled identically, except that duodenal fluid or a trypsintrypsin inhibitor mixture was added to them just before incubation with toxoid. After further incubation of the antitoxin-toxoid mixtures $\left(24 \mathrm{hr}, 4^{\circ} \mathrm{C}\right)$, the precipitates were washed with cold borate-buffered saline, dissolved in $0.6 \mathrm{ml}$ of $0.5 \mathrm{~N} \mathrm{NaOH}$, and the radioactivity was measured. The amount of toxoid bound by the precipitated immunoglobulin was estimated by comparing the sample's radioactivity with that of standard tubes containing a known amount of toxoid- ${ }^{125} \mathrm{I}$. The amounts of labeled toxoid bound by enzymetreated and untreated antitoxins were compared.

\section{RESULTS}

Digestion of exocrine and serum immunoglobulins. Colostral 11S IgA, serum IgA, or IgG (0.3-1.5 g/100$\mathrm{ml}$ solutions) were incubated with trypsin, chymotrypsin, or duodenal fluid at $38^{\circ} \mathrm{C}$ for $8 \mathrm{hr}$ in $0.05 \mathrm{M}$ Tris- $\mathrm{HCl}$ buffer, $\mathrm{pH}$ 8.0. The ratio of trypsin or chymotrypsin to immunoglobulin was $1: 23(\mathrm{w} / \mathrm{w})$. Duodenal fluid was diluted 2- to 5 -fold in Tris- $\mathrm{HCl}$ buffer so that its proteolytic activity, measured by casein digestion, was similar to that of trypsin. Thus the proteolytic activity of the fluid was less and the immunoglobulin 


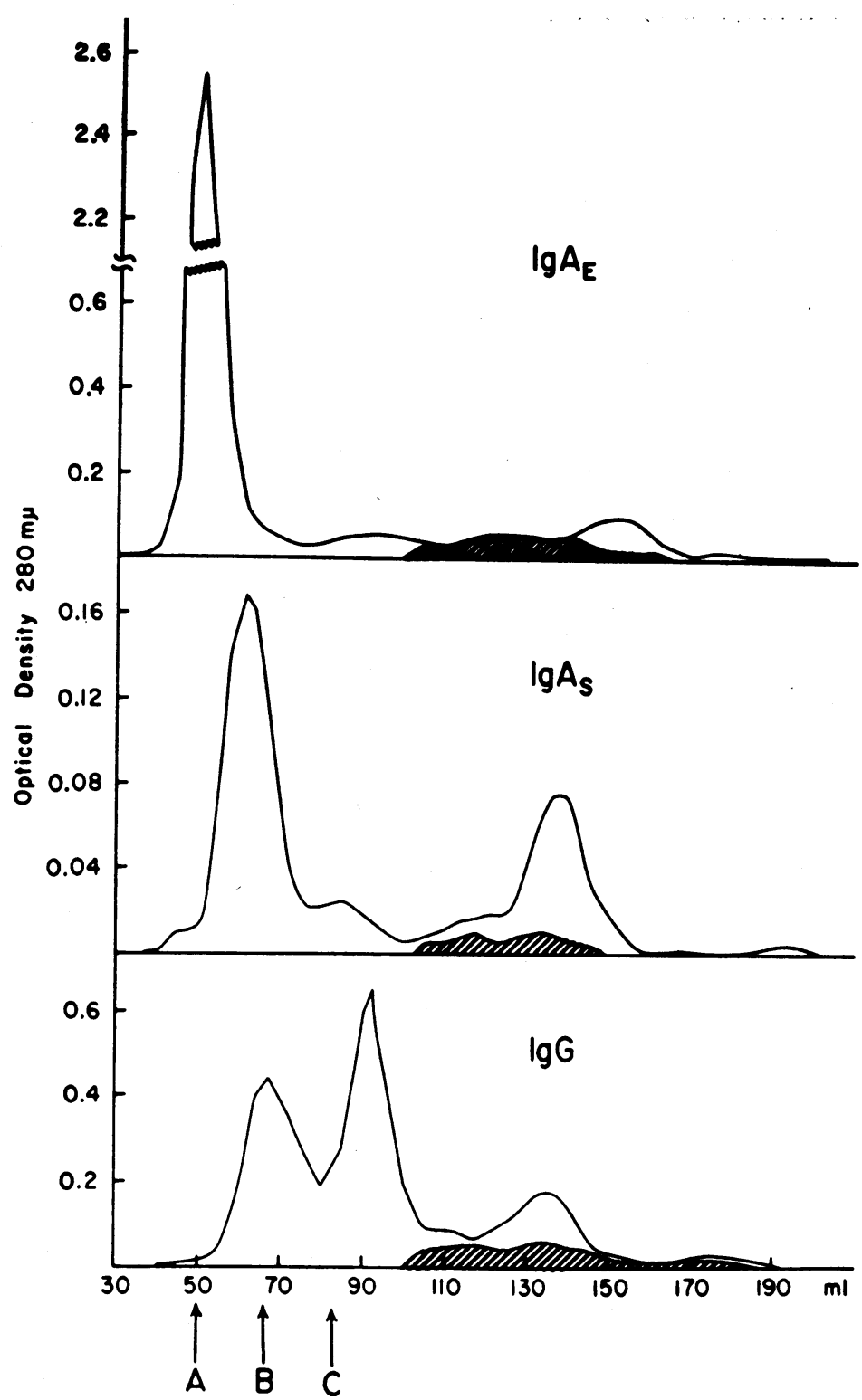

FIGURE 1 Separation of trypsin-digested immunoglobulins by gel filtration on Sephadex G-150. $\operatorname{Ig} A_{\mathrm{I}}$, exocrine (colostral) $\operatorname{IgA} ; \operatorname{Ig} \mathrm{A}_{\mathrm{s}}$, serum IgA. Areas due to trypsin and trypsin inhibitor are cross-hatched. The elution volumes of untreated colostral $11 \mathrm{~S} \operatorname{IgA}$, serum $\operatorname{IgG}$, and human serum albumin are indicated by the arrows $\mathrm{A}, \mathrm{B}$, and $\mathrm{C}$, respectively.

concentrations many times greater than those usually found in duodenal fluid (2-4). (Trypsin digestion was stopped by the addition of a 2-fold excess (w/w) of soybean trypsin inhibitor; chymotrypsin and duodenal fluid digestion was stopped by freezing.) Digestion mixtures were fractionated by Sephadex G-150 gel filtration (Fig. 1).

After digestion of colostral IgA with trypsin or chymotrypsin, nearly all protein eluted as a single peak in the volume corresponding to that of untreated $11 \mathrm{~S}$ IgA. Antigenic analysis demonstrated that the protein contained $\alpha$-chain, light-chain, and SP antigenic determinants on a single molecule. A very small amount of small peptides also was eluted. Similar results were obtained when IgA preparations from two other colostrum pools were digested with trypsin. After digestion with duodenal fluid, colostral IgA yielded two additional small peaks. The first peak, a shoulder on the 11S 


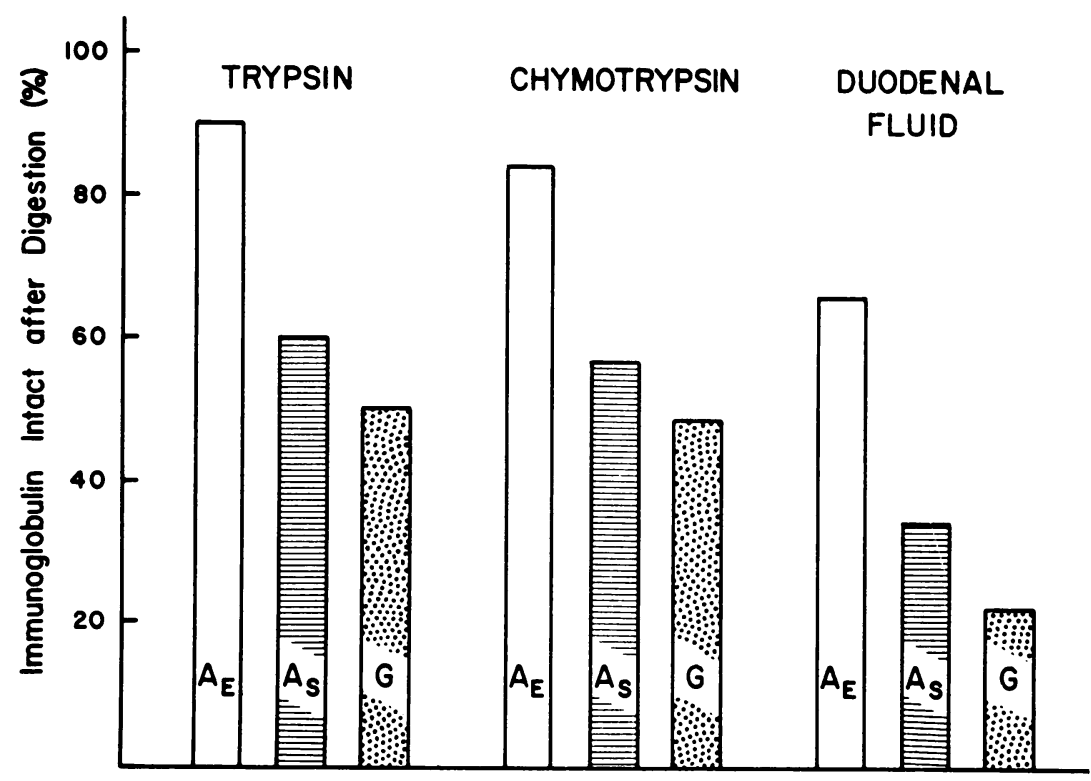

FIGURE 2 Percentages of immunoglobulins remaining intact after digestion. Percentages were calculated from gel filtration curves (Fig. 1). AE, exocrine (colostral) IgA ; As, serum IgA ; G, serum IgG.

peak, eluted slightly earlier than IgG, and contained $\alpha$-chain and light-chain determinants, but no SP determinants. Less than $3 \%$ of the recovered material was in this peak. The second small peak eluted slightly later than albumin and had only light-chain determinants. About $90 \%$ of the immunoglobulin which was degraded was degraded to peptides.

Trypsin, chymotrypsin, or duodenal fluid digests of serum IgA contained a major peak which eluted in the volume corresponding to that of the untreated protein and which contained $\alpha$-chain and light-chain determinants. A much smaller peak, which eluted slightly later than albumin and contained only light-chain determinants, and considerable small peptide material also were produced.

All three enzyme preparations degraded most of $\mathrm{IgG}$ to fragments antigenically identical to Fab and Fc fragments of papain-digested IgG as well as to small peptides.

The per cent of each immunoglobulin remaining intact after digestion was calculated from the gel filtration elution curves. The total area under each curve and the area attributable to undegraded protein were estimated separately; the area attributable to enzyme or duodenal fluid protein was excluded. $85-90 \%$ of colostral IgA was intact after digestion with trypsin or chymotrypsin, whereas only about $45-60 \%$ of serum $\operatorname{IgA}$ or IgG were intact (Fig. 2). Duodenal fluid more effectively degraded all three immunoglobulins, but colostral IgA was still most resistant. Serum $\operatorname{IgA}$ was slightly more resistant than IgG.
The stability of immunoglobulins in duodenal fluid was assessed further under conditions more closely simulating those within the duodenal lumen. Undiluted duodenal fluids containing physiologic concentrations $(2,3)$ of immunoglobulins were incubated at $38^{\circ} \mathrm{C}$ for $8 \mathrm{hr}$, and concentrations of the immunoglobulins before and after incubation were estimated by radial immunodiffusion. When duodenal fluids containing 0.30 and $0.44 \mathrm{mg} / \mathrm{ml}$ of IgA from two immunologically normal adults were incubated, the IgA concentrations decreased to 70 and $75 \%$, respectively, of preincubation concentrations (Table $\mathrm{I}$ ). ( $\operatorname{IgA}$ in these unincubated fluids was proven to be the $11 \mathrm{~S}$ exocrine variety by antigenic analysis and gel filtration separation.) When serum IgG was added to these fluids to achieve concentrations of $0.3 \mathrm{mg} / \mathrm{ml}$ and the mixtures incubated, IgG concentrations decreased to 18 and $27 \%$ of the preincubation values. Colostral $\operatorname{IgA}$, serum $\operatorname{IgA}$, or $\operatorname{IgG}(0.3 \mathrm{mg} / \mathrm{ml})$ were incubated in duodenal fluids from two hypogammaglobulinemic patients. Digestion caused much less reduction in the concentration of colostral IgA than in the concentrations of serum IgA or IgG (Table I). Proteolytic activities of the fluids. measured by casein digestion. were equivalent to $0.5-2.5 \mathrm{mg}$ of trypsin per $\mathrm{ml}$.

The possibility was considered that $\operatorname{Ig}$ A concentrations in the digests may have been overestimated because of the presence of large amounts of immunoglobulin fragments with $\alpha$-chain determinants. An aliquot of the duodenal fluid-colostral $\operatorname{Ig} \mathrm{A}$ digest in which the $\operatorname{IgA}$ 
TABLE I

Decrease in Concentration of Immunoglobulins Incubated for $8 \mathrm{hr}$ in Whole Duodenal Fluid

\begin{tabular}{lccc}
\hline \multirow{2}{*}{ Duodenal fluid* } & $\begin{array}{c}\text { Secretory } \\
\text { IgA }\end{array}$ & $\begin{array}{c}\text { Serum } \\
\text { IgA }\end{array}$ & IgG \\
\hline \multirow{3}{*}{ Normal } & $\begin{array}{c}\text { \% of preincubation } \\
\text { concentration }\end{array}$ \\
& 75 & - & 18 \\
$\gamma$-Globulin-deficient & 70 & - & 27 \\
& 57 & 14 & 11 \\
& 79 & 27 & 24 \\
\hline
\end{tabular}

* Colostral IgA, serum IgA, and IgG were added to the $\gamma$ globulin-deficient fluids; serum IgG was added to the normal fluids.

concentration was estimated by immunodiffusion to have decreased to $57 \%$ of the preincubation concentration (Table I) was separated on a column of Sephadex G-150. IgA in the eluted fractions was then estimated by the radial immunodiffusion system augmented by radiolabeled antibody. After digestion $51 \%$ of the immunoglobulin was recovered in the volume corresponding to that of undigested colostral $\operatorname{IgA}$, and only about $10 \%$ of material with heavy-chain determinants was found in later-eluting fractions.

Digestion of reduced-alkylated colostral IgA and assessment of trypsin inhibitory activity of IgA. Monomeric 7S IgA isolated from reduced and alkylated 11S IgA was digested with trypsin at an enzyme: immunoglobulin ratio of $1: 25(\mathrm{w} / \mathrm{w})$ in $0.05 \mathrm{~m}$ Tris- $\mathrm{HCl}$ buffer, $\mathrm{pH}$ 8.0. After $8 \mathrm{hr}$ at $38^{\circ} \mathrm{C}$, virtually all immunoglobulin had been degraded to small peptides or to fragments with light-chain determinants only.

In order to exclude the possibility that exocrine $\operatorname{IgA}$ or SP possesses trypsin inhibitory activity, trypsin hydrolysis of TAME was measured in the presence or absence of colostral IgA or free SP. Addition of a 25fold excess $(w / w)$ of either protein to the incubation mixture containing $0.7 \mu \mathrm{g}$ of trypsin did not significantly decrease the rate of hydrolysis. A 4-fold excess of soybean trypsin inhibitor caused nearly complete inhibition.

Diphtheria antitoxin digestion. When either the serum IgG or nasal IgA antitoxin preparation was treated with trypsin and precipitated with anti-Fab antibodies, the amount of toxoid bound by precipitated antitoxin was approximately $100 \%$ of that bound in the untreated preparations (Table II). This finding indicated that the antigen binding sites in the antitoxin molecules had not been degraded by digestion. When anti- $\gamma$ chain antibodies were added to the toxoid-IgG antitoxin mixture ( $17 \mathrm{hr}$ incubation), only $19 \%$ of the bound toxoid was precipitated, whereas anti- $\alpha$ chain antibodies added to the $\operatorname{IgA}$ antitoxin digest coprecipitated $93 \%$ of $\operatorname{IgA}$ - bound toxoid, and $85 \%$ was precipitated by anti-SP antibodies.

The antitoxins were also digested for $3 \mathrm{hr}$ in duodenal fluid having proteolytic activity equivalent to $1.3 \mathrm{mg}$ of trypsin per $\mathrm{ml}$ (about 200 times greater activity than that of trypsin in the preceding experiment). After digestion, only $16 \%$ of toxoid bound by IgG antitoxin was coprecipitated by anti- $\gamma$ chain antibodies, whereas $84 \%$ of toxoid bound to exocrine IgA antitoxin was coprecipitated by anti- $\alpha$ chain antibodies. The greater susceptibility of IgG antitoxin to digestion was also demonstrated in a $3 \mathrm{hr}$ incubation with trypsin (Table II).

\section{DISCUSSION}

The studies consistently demonstrated that exocrine IgA was more resistant to proteolytic digestion than were $\operatorname{IgG}$ or serum $\operatorname{IgA}$ immunoglobulins or antibodies. The 11S quaternary structure of exocrine $\operatorname{IgA}$ evidently remained largely intact after digestion, as indicated by chromatographic fractionation and antigenic analysis of digested colostral IgA, and by the finding that the antigen combining ability of trypsin-digested nasal $\operatorname{IgA}$ antitoxin had not been dissociated from its $\alpha$ chains or SP. The superior stability of exocrine $\operatorname{IgA}$ even at physiologic concentrations in undiluted duodenal fluid was impressive. After a $3 \mathrm{hr}$ incubation in fluids with potent proteolytic activity, more than $80 \%$ of $\operatorname{IgA}$ antitoxin was precipitated with anti- $\alpha$ chain antibodies, whereas only $16 \%$ of $\operatorname{IgG}$ antitoxin was precipitated by antibodies of $\gamma$ chains. In immunodiffusion experiments, the concentration of exocrine IgA incubated in duodenal fluid decreased much less than did the concentrations of IgG and serum IgA. Because digested serum and exocrine $\operatorname{IgA}$ both yielded no or only small amounts of heavy chain-containing fragments, the immunodiffusion estimates of immunoglobulin concentrations probably accurately reflect the difference in stability between exocrine and serum $\operatorname{IgA}$. On the other hand, estimates of $\operatorname{IgG}$ concentrations in digests probably were elevated modestly by the presence of $\mathrm{Fc}$ fragments. This artifact would have caused the amount of IgG degraded to be underestimated, and thus would not have influenced the conclusion that exocrine $\operatorname{IgA}$ is more resistant to duodenal fluid digestion than is IgG.

Studies using diphtheria antitoxins revealed that differences in resistance of exocrine $\operatorname{IgA}$ and $\operatorname{IgG}$ antibodies to trypsin were due to differences in lability of the $\mathrm{Fc}$ portions of the molecules. After a $17 \mathrm{hr}$ digestion. exocrine IgA antitoxin was almost entirely precipitated by anti- $\alpha$ chain antibodies, whereas only a small fraction of IgG antitoxin was precipitated by anti- $\gamma$ chain antibodies. These findings indicated that the $F_{c}$ portions of most IgG antitoxin molecules had been degraded or cleaved, while the corresponding portions of most $\operatorname{IgA}$ 
antitoxin molecules were antigenically intact and attached to their Fab units. On the other hand, digested IgG and exocrine IgA antitoxins both completely retained toxoid binding ability that could be precipitated by antibodies to light chains, indicating that the Fab portions of both immunoglobulins remained intact and were equally resistant to digestion.

Why exocrine IgA resists tryptic hydrolysis is unknown, but the explanation may lie in the complex quaternary structure of the immunoglobulin, which consists of dimers of $7 \mathrm{~S}$ IgA bound to SP by noncovalent and disulfide linkages acting in concert $(5,13)$. We did not find that $\gamma \mathrm{A}$ monomers derived from reduced and alkylated IgA are unusually stable; however, because reduction and alkylation may have affected the lability of the 7S molecules, this evidence is not conclusive. The possibility that $\operatorname{Ig} \mathrm{A}_{2}$ proteins, which constitute a higher proportion of $\operatorname{IgA}$ in secretions than in serum $(23,24)$, are more resistant to proteolysis than are $\operatorname{Ig} A_{1}$ proteins was not investigated. It seems unlikely, however, that the modest differences reported in IgA subclass concentrations could account for the large difference in resistance of serum and exocrine $\operatorname{IgA}$ to whole duodenal fluid digestion. The polymer fraction of serum $\operatorname{IgA}$, held together exclusively by disulfide bonds, is reportedly susceptible to enzymatic hydrolysis (11), suggesting that SP may stabilize the exocrine IgA molecule. Although this possibility is attractive, the essential role of SP in maintaining the quaternary structure of exocrine IgA has not been established (nor was free SP or exocrine IgA effective in inhibiting trypsin). The finding that $\alpha$-chain proteins from patients with intestinal lymphoproliferative diseases form polymers in vivo that are held together both by disulfide bonds and noncovalent forces (25) suggests that the similar linkages of exocrine IgA may be sufficient for stabilization of the immunoglobulin. Since the $\alpha$-chain disease protein polymers are more resistant to digestion with papain ( $25 \mathrm{a}$ ) and pepsin ${ }^{1}$ than $\gamma \mathrm{A}$ myeloma globulins are, the resistance of exocrine IgA to tryptic digestion may also be independent of the SP component.

Our findings are consistent with previous studies of tryptic degradation of immunoglobulins. Trypsin cleaves IgG principally into biologically-active $\mathrm{Fab}$ and $\mathrm{Fc}$ fragments $(26,27)$. Fab fragments of trypsin-digested IgG antibodies were found to retain antigen-binding ability (27). Papain degrades normal serum and myeloma IgA to $3.5 \mathrm{~S}$ fragments corresponding to the $\mathrm{Fab}$ portion of IgG, but no fragments corresponding to $\mathrm{Fc}$ fragments are produced (28). Cederblad, Johansson, and Rymo (29) found colostral IgA difficult to degrade with trypsin until they added $0.01 \mathrm{M}$ cysteine. Considerable amounts of Fab-like fragments, but no Fc-like fragments,

${ }^{1}$ Seligmann, M. Personal communication.
TABLE II

Toxoid Binding Activity of Diphtheria Antitoxins after Digestion

\begin{tabular}{|c|c|c|c|c|c|}
\hline \multicolumn{3}{|c|}{ Digestion } & \multicolumn{3}{|c|}{ Precipitated by antibodies to } \\
\hline Enzyme & & Antitoxin & $\begin{array}{c}\text { Heavy } \\
\text { chain }\end{array}$ & Fab & SP \\
\hline & $h r$ & & $\%$ & $\%$ & $\%$ \\
\hline Trypsin & 17 & IgG & 19 & 102 & - \\
\hline $\mathrm{E}: \mathrm{S}, * \quad 1: 23$ & & $\operatorname{IgA}$ & 93 & 103 & 85 \\
\hline Duodenal fluid & 3 & $\operatorname{IgG}$ & 16 & 一 & - \\
\hline & & $\operatorname{IgA}$ & 84 & 一 & - \\
\hline Trypsin & 3 & $\operatorname{IgG}$ & 52 & 103 & - \\
\hline $\mathrm{E}: \mathrm{S}, \quad 1: 10$ & & $\operatorname{IgA}$ & 89 & 97 & - \\
\hline
\end{tabular}

* Enzyme:substrate (immunoglobulin) w/w.

then were produced. The presence of cysteine, which also enhances tryptic digestion of $\gamma \mathrm{G}$ globulins (26), may explain the greater degradation of colostral $\operatorname{IgA}$ in their studies than in ours. In contrast to our conclusions regarding tryptic digestion of immunoglobulins, Wilson and Williams (30) concluded that exocrine IgA is not especially resistant to peptic digestion, because pepsin-digested colostral IgA yielded an amount of peptides intermediate between amounts produced by two groups of IgA myeloma proteins. The relative susceptibility of serum and exocrine immunoglobulins to peptic digestion therefore may differ from their susceptibility to tryptic digestion, although the gel filtration data presented by Wilson and Williams actually suggest that less colostral IgA than either group of myeloma proteins was degraded to fragments smaller than the parent molecules, despite similarities in the amounts of peptides produced.

Whether secretory IgA enjoys biological advantages because of its resistance to digestion is uncertain, since in these studies the antigen-binding ability of both IgG and exocrine $\operatorname{IgA}$ antitoxin molecules were unaffected by tryptic digestion. On the other hand, the biological role of the Fc portion of IgA, which is protected in exocrine $\operatorname{IgA}$, is unknown. Neither serum nor exocrine IgA fix complement after nonspecific aggregation (3133 ) or in antigen-antibody complexes (34). An important role for the $\mathrm{F}_{\mathrm{c}}$ portion of $\operatorname{IgA}$ probably will be established, nevertheless, because the corresponding portions of other immunoglobulins (IgG, IgM, and IgE) are biologically important. The biological significance of the resistance of secretory immunoglobulins to tryptic digestion deserves investigation.

\section{ACKNOWLEDGMENTS}

We are grateful to Mrs. Bonita L. DeVald for technical assistance. 
This research was supported in part by U. S. Public Health Service Grants AI-08500 and FR-05357 and American Cancer Society Institutional Grant No. IN-5J to the University of Colorado Medical Center.

\section{REFERENCES}

1. Brown, W. R., R. W. Newcomb, and K. Ishizaka. 1969. Proteolytic degradation of secretory and serum immunoglobulins and diphtheria antitoxins. Clin. Res. 17: 535.

2. Plaut, A. G., and P. Keonil. 1969. Immunoglobulins in human small intestinal fluid. Gastroenterology. 56: 522.

3. Brown, W. R. 1969. Immunoglobulins of intestinal fluid. Gastroenterology. $57: 368$.

4. Chodirker, W. B., and T. B. Tomasi, Jr. 1963. Gammaglobulins: quantitative relationships in human serum and nonvascular fluids. Science (Washington). 142: 1080.

5. Tomasi, T. B., Jr., E. M. Tan, A. Solomon, and R. A. Prendergast. 1965. Characteristics of an immune system common to certain external secretions. J. Exp. Med. 121: 101.

6. Ogra, P. L., D. T. Karzon, F. Righthand, and M. MacGillivray. 1968. Immunoglobulin response in serum and secretions after immunization with live and inactivated poliovaccine and natural infection. N. Engl. J. Med. 279: 893.

7. Berger, R., E. Ainbender, H. L. Hodes, H. D. Zepp, and M. M. Hevizy. 1967. Demonstration of IgA polioantibody in saliva, duodenal fluid and urine. Nature (London). 214: 420 .

8. Hodes, H. L., R. Berger, E. Ainbender, M. M. Hevizy, H. D. Zepp, and S. Kochwa. 1964. Proof that colostrum polio antibody is different from serum antibody. $J$. Pediat. 65: 1017.

9. Kenny, J. F., M. I. Boesman, and R. H. Michaels. 1967. Bacterial and viral coproantibodies in breast-fed infants. Pediatrics. 39: 202.

10. Thind, K. S. 1961. Studies of coproantibody. II. The origin and nature of coproantibody. Indian. J. Med. Res. 49: 223.

11. Tomasi, T. B., and D. Czerwinski. 1968. The secretory IgA system. In Immunologic Deficiency Diseases in Man. Birth Defects Original Article Series. D. Bergsma, editor. The National Foundation March of Dimes, New York. 4: 274

12. Tomasi, T., and N. Calvanico. 1968. Human secretory rA. Fed. Proc. $27: 617$.

13. Newcomb, R. W., D. Normansell, and D. R. Stanworth. 1968. A structural study of human exocrine IgA globulin. J. Immunol. 101: 905.

14. Vaerman, J.-P., J. F. Heremans, and C. Vaerman. 1963. Studies of the immune globulins of human serum. I. A method for the simultaneous isolation of the three immune globulins $\left(\gamma_{s s}, \gamma_{1 M}\right.$ and $\left.\gamma_{1 A}\right)$ from individual small serum samples. J. Immunol. 91: 7 .

15. Newcomb, R. W., K. Ishizaka, and B. L. DeVald. 1969. Human IgG and IgA diphtheria antitoxins in serum, nasal fluids and saliva. J. Immunol. 103: 215.

16. Kunitz, M. 1947. Crystalline soybean trypsin inhibitor. II. General properties. J. Gen. Physiol. 30: 291.

17. Hummel, B. C. W. 1959. A modified spectrophotometric determination of chymotrypsin, trypsin and thrombin. Can. J. Biochem. Physiol. 37: 1393.
18. Hong, R., J. L. Palmer, and A. Nisonoff. 1965. Univalence of half-molecules of rabbit antibody. J. Immunol. 94: 603 .

19. Ouchterlony, O. 1962. Diffusion-in-gel methods for immunological analysis. II. Progr. Allergy. 6: 30.

20. Mancini, G., A. O. Carbonara, and J. F. Heremans. 1965. Immunochemical quantitation of antigens by single radial immunodiffusion. Immunochemistry. 2: 235.

21. Rowe, D. S. 1969. Radioactive single radial diffusion: a method for increasing the sensitivity of immunochemical quantification of proteins in agar gel. Bull. World Health Organ. 40: 613.

22. Newcomb, R. W., and K. Ishizaka. 1967. Human diphtheria antitoxin in immunoglobulin classes IgG and IgA. J. Immunol. 99: 40.

23. Vaerman, J.-P., H. H. Fudenberg, C. Vaerman, and W. J. Mandy. 1965. On the significance of the heterogeneity in molecular size in human serum $\gamma \mathrm{A}$-globulins. Immunochemistry. 2: 263.

24. Grey, H. M., C. Abel, W. J. Yount, and H. G. Kunkel. 1968. A subclass of human $\gamma \mathrm{A}$-globulins $\left(\gamma \mathrm{A}_{2}\right)$ which lacks the disulfide bonds linking heavy and light chains. J. Exp. Med. 128: 1223.

25. Seligmann, M., E. Mihaesco, D. Hurez, C. Mihaesco, J.-L. Preud'homme, and J.-C. Rambaud. 1969. Immunochemical studies in four cases of alpha chain disease. J. Clin. Invest. 48: 2374.

25a. Seligmann, M., F. Danon, D. Hurez, E. Mihaesco, J.-L. Preud'homme. 1968. Alpha-chain disease: a new immunoglobulin abnormality. Science (Washington). 162: 1396

26. Schrohenloher, R. E. 1963. The degradation of human $\gamma$-globulin by trypsin. Arch. Biochem. Biophys. 101: 456.

27. Hanson, L. A., and B. G. Johansson. 1963. Isolation of immunologically active fragments of normal human $\gamma$-globulin after tryptic degradation. Clin. Chim. Acta. 8: 66.

28. Bernier, G. M., K. Tominaga, C. W. Easley, and F. W. Putnam. 1965. Structural studies of the immunoglobulins. II. Antigenic and chemical properties of the $\gamma \mathrm{A}$ myeloma globulins. Biochemistry. 4: 2072.

29. Cederblad, G., B. G. Johansson, and L. Rymo. 1966. Reduction and proteolytic degradation of immunogloblin A from human colostrum. Acta Chem. Scand. 20: 2349.

30. Wilson, I. D., and R. C. Williams, Jr. 1969. Two distinct groups of immunoglobulin A (IgA) revealed by peptic digestion. J. Clin. Invest. 48: 2409.

31. Ishizaka, T., K. Ishizaka, T. Borsos, and H. Rapp. 1966. $\mathrm{C}^{\prime} 1$ fixation by human isoagglutinins: fixation of $\mathrm{C}^{\prime} 1$ by $\gamma \mathrm{G}$ and $\gamma \mathrm{M}$ but not by $\gamma \mathrm{A}$ antibody. J. Immunol. 97: 716.

32. South, M. A., M. D. Cooper, F. A. Wollheim, R. Hong, and R. A. Good. 1966. The IgA system. I. Studies of the transport and immunochemistry of $\operatorname{IgA}$ in the saliva. J. Exp. Mcd. 123: 615

33. Ishizaka, T., K. Ishizaka, S. Salmon, and H. Fudenberg. 1967. Biological activities of aggregated $\gamma$-globulin. VIII. Aggregated immunoglobulins of different classes. $J$. Immunol. 99: 82

34. Newcomb, R. W., and B. L. DeVald. 1969. Antibody activities of human exocrine $\gamma \mathrm{A}$ diphtheria antitoxin. Fed. Proc. 28: 765. 